\title{
The Kansas-Nebraska Act in lowa: A Case Study
}

\author{
by Morton M. Rosenberg .
}

The Kansas-Nebraska Act has generated a wealth of historical writing since its passage. Most of the work of historians, however, has been focused upon the national setting of the measure and upon its implications as viewed in a national context. This study examines the significance of the act for the western state which was largely responsible for its initial introduction in Congress. ${ }^{1}$

The story of Iowa's relationship with Nebraska and of the efforts of her citizens to secure the political organization of that area is extremely interesting as well as instructive. Iowans had long been intrigued by the territory just across the Missouri River. The causes behind this concern appear to have been primarily twofold. In the first place, Nebraska contained a vast area of land dearly coveted by eager, land-hungry westerners. The Indian title to the land, however, still reposed in the hands of the redmen; and unless the territory were organized by the Federal government, the title would continue to remain there. Organization of Nebraska not only would clear the land of its Indian titles, but would also open that vast tract to white settlers, large numbers of whom would come from, and through, Iowa. Businessmen, among others, could expect to reap large profits by supplying Nebraskabound travelers. ${ }^{2}$

The railroad was another important factor in the desire of Iowans to secure the organization of Nebraska. Iowans had long sought a grant of land from Congress to aid railroad construction in the state. If the national leaders of the party in power could be shown that Iowa lay on a direct route for the much desired railroad to the Pacific, perhaps they would approve grants of land for the state. Such a Pacific line would,

1 Roy F. Nichols, "The Kansas-Nebraska Act: A Century of Historiography," Mississippi Valley Historical Review, Sept. 1956, 187-212; cf. R. W. Johannsen, "The Kansas-Nebraska Act and the Pacific Northwest Frontier," Pacific Historical Review, May, 1953, 129-141.

2 Iowa State Gazette, Dec. 8, 1853; David S. Sparks, "The Decline of the Democratic Party in Iowa, 1850-1860," Iowa Journal of History, LIII, $1955,15$. 
of course, run across Iowa and Nebraska, but the latter must first be organized. Even if a mainline for a Pacific railroad did not pass through the state, track construction in Iowa could feed into a Pacific route. Indeed, the agitation for a transcontinental route motivated lowa's congressmen to seek the organization of Nebraska. ${ }^{3}$

As early as 1850 the Iowa Legislature passed a memorial and joint resolution requesting Congress to organize Nebraska. No action was taken in Washington at this time. Iowa itself, was barely occupied. Most of her residents lived in the eastern portions of the state along the Mississippi, in the southern counties just north of the Missouri line, and in small clusters on the Missouri slope, principally at Council Bluffs. Elsewhere, the vast acreage of the state remained uninhabited. Since Iowa was only sparsely settled, the organization of a territory directly to her west was still unnecessary. ${ }^{4}$

Agitation in Iowa for the organization of Nebraska, however, recurred in 1853. Meetings held at Glenwood, Mills county, in October, and at Sidney, Fremont county, in November, asked for the elimination of the Indian titles in Nebraska and called for its organization as a territory. Early in January, 1854, a Democratic convention in Pottawattamie county declared that "the immediate organization of Nebraska and the establishment of a territorial government over its citizens is a question of national importance and greatly affecting the interests of western Iowa." 5

If an additional incentive was needed to arouse Iowans over Nebraska, the people of Missouri supplied it. They were also interested in Nebraska for much the same reasons as the Iowans. A mass meeting held in St. Louis, presumably by the friends of Missouri Senator Thomas H. Benton, included among its resolutions one which stated that the assembly "was

3 Frank H. Hodder, "Genesis of the Kansas-Nebraska Act" in Proceedings of the State Historical Society in Wisconsin Oct. 24, 1912 (Madison, 1913), 69.

4 Journal of the House, Third General Assembly of Iowa, 1850, 255; "The Seventh Census of the United States." Manuscript census reports for Iowa.

5 Iowa State Gazette, Jan. 11, 1854; Burlington Daily Telegraph, Nov. 4, 1853; P.. Orman Ray, The Repeal of the Missouri Compromise (Cleveland, 1909), 176-177. 
in favor: of a territorial government for Nebraska . . . and regarded all who oppose it upon whatever pretext as hostile to the best interests of the state." 6

While Iowans drew up resolutions and petitions, Missourians were acting. In the fall of 1853 , a Methodist missionary to the Shawnee Indians, Thomas Johnson, was elected Delegate to Congress from the unorganized territory of Nebraska, and set out for Washington. A rival, Abelard Guthrie, also claiming the office, likewise headed for Washington to present his case. ${ }^{7}$

The people of Iowa, however, were not to be outmaneuvered. As soon as the settlers along the Missouri slope learned of the call which resulted in the selection of Thomas Johnson, they crossed the river at Council Bluffs to conduct their own balloting. Hadley D. Johnson journeyed to Washington as the Delegate-elect of this "election." There he joined his Missouri namesake in pressing Congress to organize Nebraska as well as to recognize the legality of his election. ${ }^{8}$

At the opening of the new Congress, December 5, 1853, Senator Augustus C. Dodge gave notice of his intention to introduce a bill providing for the establishment of a territorial government for Nebraska. On December 14, he introduced his bill which was promptly referred to the Committee on Territories of which Stephen A. Douglas of Illinois was chairman and George W. Jones of Iowa was a member. It is significant that Dodge had visited his constituents in western Iowa prior to the opening of Congress. There he undoubtedly learned about the desires of the border residents concerning Nebraska and about the election of the two Johnsons. ${ }^{9}$

On January 23, 1854, Chairman Douglas, reporting for the Committee on Territories, recommended that Congress split Nebraska into two territories. The necessity for a division of Nebraska stemmed in part from the election of the two Johnsons. Both men wanted to be seated as duly elected delegates,

6 Quoted in Ibid., 173.

7 George Fort Milton, The Eve of Conflict: Stephen A. Douglas and the Needless War (New York, 1934), 107; James C. Malin, The Nebraska Question 1852-1854 (Lawrence, 1953); 182.

8 Milton, Eve of Conflict, 107.

9 Congressional Globe 1st Session 33rd Congress, 1, 44; Ray, Repeal of the Missouri Compromise, 177, 1.95. 
and both had the support of the Missouri and Iowa Congressmen, respectively. Moreover, the Iowa Johnson demonstrated that it would be to Iowa's best interests to split Nebraska instead of permitting the organization of one terriory as contemplated in Dodge's original bill. The title of the Omaha Indians, directly to the west of Iowa, had not yet been extinguished. If Nebraska were organized as one large territory, the center of population would likely fall to the south of Iowa. This could result in a Pacific railroad running south of the state, thereby jeopardizing the interests of Iowa in her competition with Missouri for the route. The possibility of securing additional patronage for distribution among loyal Iowa Democrats may have been further motivation for a division. Iowa's Senators decided to ask for a split, and they conveyed this decision to Senator Douglas. Nebraska was divided along the fortieth parallel, and the Kansas-Nebraska Act took concrete form, with Iowa's Senators listed among its most ardent supporters. ${ }^{10}$

Although Iowans both in and out of Congress had supported the measure, the publication in Iowa of the provisions of the proposed Kansas-Nebraska measure provoked a sharp reaction as proponents of the measure and its critics formed their lines of battle. While the Whig press generally condemned the Nebraska bill,-. the papers which supported the Democratic party were divided over the issue. Such influential journals as the Miner's Express of Dubuque, the Sentinel of Fairfield, and the Iowa State Gazette of Burlington backed the bill. Other papers, including the Iowa City Capital Reporter, the Muscatine Democratic Enquirer, the Davenport Banner, the Cedar Rapids Progressive Era, and the Lee County Plaindealer opposed the measure. ${ }^{11}$

Acting as unofficial spokesman for this group of dissenting newspapers, the organ in Muscatine declared:

We believe it to be wrong and undemocratic to override a solemn national compact-to open again the bleeding wounds of the country - to violate the pledge of the democratic party, made at Baltimore

10 Milton, Eve of Conflict, 148; Congressional Globe, lst Session 33rd Congress, 221.

11 Burlington Daily Telegraph, Jan. 23, Feb. 20, Feb. 21, 1854. 
in 1852 to discontenance the slavery question.

We believe these things to be undemocratic and all these things the supporters of the Nebraska Bill are doing.12

In defense of the measure one Democratic paper based its approbation on the ground that the question of slavery or free soil should be left to the actual settlers of the new territories. As for the Missouri Compromise, which critics of the Nebraska bill hastened to defend, the Compromise of 1850 had virtually terminated its operation. In any case, to make the act of one Congress binding forever on its successors is "radically wrong and an outrage on all free institutions; and the attempt to give imperative validity to the compromise of 1820 is nothing less." 13

Though the Democracy at home was divided, the Democratic members of Congress from Iowa were unanimous in their support of the Kansas-Nebraska legislation. Apparently unconcerned about the sudden protests emanating from his state, Senator Dodge vigorously championed the bill before the Senate. He defended popular sovereignty as "the noblest tribute which has ever yet been offered by the Congress of the United States to the sovereignty of the people." To win friends for the act, Dodge endeavored to identify it with the Compromise of 1850 and Manifest Destiny, ever popular in the West. At the same time he justified the repeal of the Missouri Compromise. The latter, he declared, represented, with similar measures, "dangerous assumption of power" and were "as manifest usurpations as a law would be which should require all settlers to purchase and hold one or more negroes as slaves." Opponents of the bill, Dodge insisted, were merely using the issue of slavery as a means to gain political power. Concluding his remarks, Dodge declared that "the passage of the bill before us will, in my judgement, confer great benefits upon the nation, the West, and especially upon the State which I in part represent. The settlement and occupation of Nebraska will accomplish for us what the acquisition and peopling of Iowa did for Illinois."14

12 Iowa Democratic Enquirer quoted in The Iowa Weekly Republican, March 8, 154.

13 Iowa State Gazette, Feb. 15, 1854.

14. Congressional Globe 1st Session 33rd Congress. Appendix. 376-382. 
Dodge's speech in behalf of the Nebraska act was, perhaps, the most forceful and eloquent address he ever delivered to the Senate. Regardless of whether his words swayed any of his colleagues, they were reprinted in Democratic papers in various parts of the country. The Boston Statesman reviewed his speech as "strong, manly and straight-forward." 15 Stephen Hempstead, Iowa's retiring Governor, wrote that Dodge's was "the best speech on that question." 16

Senator Jones confined his remarks to an attack on the Clayton amendment, which, sponsored by Senator Clayton of Delaware, limited the right of suffrage and of office-holding to citizens of the United States exclusively. Had Jones gone farther, he could have contributed little to what Dodge had already expressed.

In the House of Representatives Iowa's Congressmen were divided over the act. John P. Cook, the lone Whig member from Iowa, based his opposition to the Nebraska bill on the three points commonly made by its critics: it repealed the Missouri Compromise and opened the way for the extension of slavery; it re-opened the slavery argument; it was contrary to the principles of the Compromise of 1850 . The views of his colleagues in the Senate, Cook insisted, did not "represent the sentiments of Iowa when they consented to the renewed agitation." 17

Four days later, Bernhard Henn of Iowa' rose to reply to Cook. He countered the latter's slavery argument by pointing out that, regardless of the repeal of the Missouri Compromise, the two territories would, of necessity, become free states because the pattern of settlement would favor immigration from non-slaveholding states. The organization of Nebraska, Henn averred, would benefit Iowa and the entire North by adding "to the commerce, wealth, and prosperity of the whole country." 18

While the battle over the Nebraska act raged in Congress,

15 March 31, 1854, quoted in Iouia State Gazette, April 12, 1854.

16 Quoted in Louis Pelzer, Augustus Caesar Dodge (Iowa City, 1908). 321-322.

17 Congressional Globe, 1st Session 33rd Congress. Appendix. 670-673.

18 Ibid., 855-888. 
political tempers began to erupt among the rank and file of the Iowa Democracy. The various county conventions, meeting to select delegates to attend the State Democratic convention at Iowa City on January 9, generally expressed a desire to work for party unity. Most voted resolutions approving the efforts of the Democratic members of Iowa's Congressional delegation and praising the Administration of Franklin Pierce. Some criticized what they termed "renegade journals and disappointed office seekers" for attempting to disrupt the narmony of the party. The Democratic convention in Pottawattamie county, especially concerned with Nebraska, adopted a resolution asking for its ultimate organization. ${ }^{19}$

After the usual preliminaries, the State Democratic convention selected Curtis Bates to head the party's ticket. A native of Connecticut, Bates had entered local politics in Ohio, where he was elected to the state Senate in 1831. Ten years later he migrated to Iowa. The other state nominations went to George W. McCleary, Secretary of State; Martin L. Morris, Treasurer; David C. Cloud, Attorney General; and P. L. Sharp, Auditor. For Superintendent of Public Instruction the convention selected James D. Eads, a choice not supported by all Democrats at the convention. One local party luminary, Ver Planck Van Antwerp, believed that Eads was totally unsuited for the position, and that the nomination was merely an attempt to undermine the current Democratic leadership. ${ }^{20}$

The state Democratic platform included the usual resolutions lauding the Pierce Administration and reaffirming the national party platform of 1852 . The most strongly "worded resolution asked for a speedy organization of Nebraska. Other planks called for party harmony and disclaimed any sectionalism. To attract the foreign element, the Democrats added that the party looked with disfavor upon efforts to hamper foreignborn persons from becoming citizens and owning land. ${ }^{2 \mathrm{i}}$

19 Iowa State Gazette, Jan. 4, 11, 1854.

20 Charles E. Snyder, "Curtis Bates," Iowa Journal of History and Politics, XLIV, 1946, 297-299; V. P. Van Antwerp to Laurel Summers, Dec. 18, 1853.

21 Roy V. Sherman, "Political Party Platforms in Iowa." Unpublished M. A. Thesis (State University of Iowa, 1926), 124-127. 
Missing from the Democratic platform were resolutions expressing the party stand on such issues as homesteads, internal improvements, and temperance. Failure to mention the first two reflected the dilemma of the party: time and again the local organization advocated Congressional action in favor of internal improvements and homestead laws, but the national leadership, emanating principally from the South, blocked these measures, leaving the local party in a precarious position. Supporters of the national administration apparently preferred to ignore these issues. Silence on the temperance question was the only way to avoid intra-party feuding, for the rank and file were divided on this issue. In addition, no plank stated the party's attitude on another local issue, the question of amending the state constitution. Thus, the Democrats of Iowa entered the political contests of 1854 with a vaguely worded, weak platform which was uncomfortably silent on most of the vital problems of local interest to the voters of the state.

Meantime, the Whigs and Free Soilers convened to select their candidates. The Whigs of Iowa met in convention virtually for the final time under this label. The party was torn by factionalism principally as a result of the slavery question. There were "Seward Whigs," "Cotton Whigs," "Consience Whigs," and "Silver Greys." All differed on the problem of slavery, but all more or less opposed its extension into the territories. The Whig gathering in Iowa City on February 22 selected James W. Grimes for the governor's chair. A native of New Hampshire and a graduate of Dartmouth, Grimes moved to Iowa in 1836. His previous experience included terms in the territorial and regular Legislatures of the state. Other Whig candidates were George Shedd, Superintendent of Public Instruction; Simeon Waters, Secretary of State; Eliphalet Price, Treasurer; A. P. Stevens, Auditor; and James W. Sennett, Attorney General. This ticket was not a solid Whig lineup, but included two nominees of the Free Soil party, George Shedd and Simeon Waters. ${ }^{22}$

22 Biographical Directory of the American Congress 1774-1949 (Washington, 1950), 1239; Snyder, "Curtis Bates," 291-929. 
In their platform the Whigs demanded a revision of the state constitution in order to permit the establishment of banks, called for a change in the educational system of the state, supported a prohibitory law, and asked for legislation for homesteads and internal improvements. In addition, they endorsed Congressman John P. Cook and denounced the Nebraska bill and its authors, calling upon Iowans to oppose the act: ${ }^{23}$

Quite evidently the Whig platform represented an attempt by certain leaders, headed by James Grimes, to persuade various splinter groups to coalesce into a single body. Only a unified opposition could hope to defeat the Democratic party in the approaching elections. Thus, the platform tried to appeal to Free Soilers, abolitionists, Whigs, temperance men, and anti-Nebraska Democrats. Though the foreign element would oppose the Whig stand on prohibition, they might favor the party's position on banking and homesteads.

Whig unity, however, was not to be so readily achieved. The anti-slavery, anti-Nebraska platform adopted by the party under Grimes' driving leadership was too strong for the conservative wing of the party known as the "Silver Grey." The abolitionist faction of the party had dominated the convention, much to the disgust of the conservatives. The Burlington Hawk-Eye, one of the leading Whig papers in the state, attacked Grimes and criticized the Whig platform. Even more disconcerting was the refusal of three of the Whig nominees, Simeon Waters, George Shedd, and Eliphalet Price, to run for office under that label. The first two men were strong Free Soilers. Signs of this Whig discord were heartening to the Democrats. One paper invited the conservatives among the Whigs to join the Democrats to fight "the fanatical disunionists of the north." 24

23 Sherman, "Political Platforms in Iowa," 124-127.

24 Cyrenus Cole, A History of the People of Iowa (Cedar Rapids, 1921), 271; Frank I. Herriott, "James Grimes Versus the Southrons, Annals of Iowa, Third Series, XV, 1925-1927, 326-327; Daily Miners' Express, May 13, 1854; Weekly Iowa State Gazette, July 5, 1854 quoted in Louis Pelzer, "The History and principles of the Democratic Party of Iowa 1846-1857," Iowa Journal of History and Politics, VI, 1908, 79-80. 
The Free Soil party met in convention in early February as the Free Democracy of Iowa Party and chose a full slate of candidates. Simeon Waters was put up for Governor and George Shedd for Superintendent of Public Instruction. Accompanying the usual Free Soil resolutions was a plank condemning the Nebraska bill. If they could have united the various anti-slavery, anti-Nebraska elements, the Free Soilers might have held the balance of power in the state. ${ }^{25}$

At this point, Grimes sought to win the Free Soilers to his banner. He approached the leaders of the movement, the Rev. Asa Turner and George F. Magoun, and arranged to secure their support. Accordingly, a new convention of the Free Democracy met at Crawfordsville, Washington county, and adopted a resolution endorsing James W. Grimes for governor. Thus, the Whigs and Free Soilers essentially combined to fight the Democrats. ${ }^{26}$

The Democrats of the First Congressional District picked Augustus Hall to oppose Whig Rufus L. B. Clarke. Hall, a New Yorker by birth, had settled in Keosauqua after winning some local repute in Ohio. Later he would become Chief Justice of Nebraska Territory. His opponent was a Connecticut Yankee who had come to Iowa in 1849 , but never had won much popularity even among his own party colleagues. ${ }^{27}$

In the Second District the Democratic Party selected the retiring governor, Stephen Hempstead, in an effort to recapture the Congressional seat lost to the Whigs in 1852. To oppose him the latter nominated James Thorington, a North Carolinian who had been reared in Alabama. Moving to Davenport in 1839, Thorington rose rapidly in local politics and became mayor of the town. A strong temperance advocate and Know-Nothing as well, he was an excellent choice to attract the splinter groups to his standard.28

25 David S. Sparks, "The Birth of the Republican Party in Iowa, 1848-1860." Unpublished Ph. D. Dissertation (University of Chicago, 1951), 79-80.

26 Ibid., 88-89; Des Moines Valley Whig, April 20, 1854; Weekly Observer, April 6, 1854; Iowa State Gazette, April 12, 1854.

27 Biographical Directory of Congress, 1251; David S. Sparks, "The Birth of the Republican Party in Iowa, 1854-1856," Iowa Journal of History, LIV, 1956, 5.

28 Biographical Directory of Congress, 1917. 
On April 8, James Grimes published a pamphlet entitled "To the People of Iowa" which contained his personal political creed, and which appeared in Whig journals throughout the state. Grimes was planning a trip to the East and apparently published this pamphlet in order to compensate for his absence. Evidently he was confident of his ability to capture the gubernatorial office without conducting an intensive personal tour of the state. Five days prior to the publication of his "Address" he wrote that he could "carry Des Moines County by a larger majority than any man ever got in it, and so far as I can learn the chances are that I can be elected." 29 About a week or so later, Grimes departed for the East.

Grimes' pamphlet was designed to furnish a common ground upon which the discordant elements in Iowa could unite in support of his candidacy. In addition, he made a strong effort to attract the foreign-born voters, particularly the Germans. Grimes advocated the popular election of judges of the Supreme Court, called for an amendment of the state constitution to permit the establishment of banks, and asked for federal aid for internal improvements. On the temperance issue he tread softly, not wishing to alienate the anti-temperance vote, and at the same time desiring to demonstrate his friendly attitude toward temperance legislation. On this point he merely stated that, if the Legislature passed a prohibitory law, he would not veto the measure unless it were manifestly unconstitutional. ${ }^{30}$

On the matter of homesteads Grimes could not successfully attack the Democrats of the state for failing to work to secure such legislation; but he could, and did, point out to the Germans and other foreign groups that the most recent homestead bill, introduced by. Bernhard Henn, contained certain discriminatory clauses which, by implication if not by intent, prevented foreigners from participating fully in a homestead program. ${ }^{31}$

29 James Grimes, "To the People of Iowa," in the William Salter Papers (Des Moines Archives); James Grimes to William Penn Clarke, April 3, 1854.

30 Grimes, "To the People of Iowa."

31 Ibid. 
Finally, Grimes came to the central topic of his "Address," the denunciation of the Nebraska act. He reviewed most of the arguments advanced against the repeal of the Missouri Compromise and the attempts to spread slavery, vowing that "the Nebraska outrage shall receive no aid or comfort from me." 32

It was partly on the Nebraska question that Grimes sought to lure the German voters to his banner, not by appealing to their anti-slavery impulses, but by emphasizing an item which had appeared in the Burlington Telegraph on March 21. This paper had noted that in a Senate speech A. P. Butler of South Carolina had made references to Iowa which, at best, were indiscreet and unfortunately timed. Butler had asserted that:

\begin{abstract}
... the slaveholder, with his slaves well governed forms a relation that is innocent enough, and useful enough. I believe that it is a population which Iowa tomorrow would prefer to an innundation of those men coming as emigrants from a foreign country, wholly unacquainted with the institutions of this country-and nearly all continental comers are of this class. This same remark cannot be made of those, who like the Irish and English, have lived under the administration of the common law. ${ }^{33}$
\end{abstract}

His pen dripping with sarcasm, Grimes denounced Butler's remarks: "In the boastfulness of anticipated triumph, the citizens of Iowa have been told by a Southern Senator how much better would be the condition of our State with negro slaves than with our foreign population." To arouse the antislavery seginents of Iowa's population, Grimes added that "a distinguished Representative from Georgia has announced? that in fifteen years, Iowa will be a slave state." ${ }^{34}$ In later weeks Grimes repeated those words on several occasions, having distorted Butler's comments to serve his own purposes.

With the Grimes' pamphlet winning the usual laudatory receptions from friendly journals, the Democratic press raked it and its author over the coals. One paper described his "Address" as "a miserable piece of the lowest kind of electioneering trickery, filled with the grossest falsehoods and misrepresentation." "35 Another declared that his remarks were not really addressed to all Iowans, but merely to certain factions.

32 Ibid.

33 Congressional Globe 1st Session 33rd Congress. Appendix. 333.

34 Grimes, "To the People of Iowa."

35 Iowa State Gazette, April 19, 1854. 
principally bankers and abolitionists. The Washington Union also denounced the Whig gubernatorial candidate. Among other things, the Union questioned Grimes' sincerity concerning his friendly feelings toward the foreign-born: "Our would-begovernor of Iowa, was doubtless, a few years ago, if he is not now, with most of his party, a native American. Like General Scott, he had doubtless cursed the foreigners after the election, though he coaxed them most affectionately before the election. The adopted citizens have always been a stumbling block to the Whigs." 36

One day prior to the publication of Grimes' pamphlet, the voters of Iowa went to the polls to select a Superintendent of Public Instruction. While the Whigs had advocated a change in the state's educational structure, the Democrats did not mention the matter. Although a last-minute substitute Whig candidate, Isaac Stevens, did appear, the withdrawal of George Shedd as the regular Whig nominee left the field virtually clear to the Democratic hopeful, James D. Eads. The latter carried the election by a vote of 17,793 to 13,462 , a manifest indication that the power of the Democrats in Iowa was still quite formidable despite the excitement which Kansas-Nebraska was generating. ${ }^{37}$

Whether the news of the Democratic victory in the contest for the educational post disturbed him, whether the attacks of the Washington Union wounded him, or whether the antislavery leaders he undoubtedly met during a side trip to Washington while on his eastern travels cautioned him, Grimes decided to cut short his stay in the East and return to Iowa to take to the stump. Undoubtedly the news from Iowa had tempered his earlier optimism. ${ }^{38}$

Arriving in Iowa in mid-May, Grimes penned another "Address" to Iowans in which he endeavored to disprove the charges hurled at him by the Union. He accused Dodge and Jones of voting for the Clayton amendment, of driving away from Iowa Northern railroad investors by catering to the

36 Quoted in Des Moines Valley Whig, May 25, 1854; Iowa State Centinal, April 20, 1854.

37 The election returns, on file in the office of the Secretary of State of Iowa, are entered in a ledger entitled Election Record 1848-1860.

38 Herriott, "James Grimes Versus the Southrons," 353, 404. 
South and of encouraging the spread of slavery. To the accusations that he constantly shifted his views to suit the occasion, Grimes rather weakly replied that experience had prompted him to modify certain of his earlier views. ${ }^{39}$

Following the publication of his second "Address," Grimes issued an itinerary for thirty-one speeches which he intended to deliver throughout the state. At the same time he challenged his Democratic adversary, Curtis Bates, to join him on his tour to debate the various issues with him. The Democratic nominee, however, refused to retrieve the gauntlet. Apparently Grimes was determined to seize and hold the initiative. When his campaign began to lag, as during his absence from the state, he returned immediately to inject new strength anj: vitality into the canvass. Bates, on the other hand, conducted his campaign in a restrained, almost lifeless manner. ${ }^{40}$

Meantime, several counties in Iowa entertained meetings. which protested against the Nebraska act. These gatherings were attended by abolitionists, Free Soilers, Whigs, temperance supporters, and anti-Nebraska democrats. Some of the opposition to the Kansas-Nebraska act stemmed from the Clayton amendment which almost became part of the act. Because of the anti-foreign nature of the amendment; abolitionists sought to convince the Germans, whom the amendment especially antagonized, that the real purpose of the entire Douglas bill was to prevent foreign-born persons from migrating to Nebraska. One Whig paper thought it only natural for the Germans to resent the measure, and explained that the Irish remained silent only because they had grown accustomed to years of oppression at the hands of the English. The editor of the influential German paper in Davenport, Theodore Guelich of Der Demokrat, was outspoken in his denunciation of Senator Douglas and the Nebraska act. $\mathrm{He}$ called for a re-alignment of the parties because the existing organizations were unable to cope with the important issues of the day. ${ }^{41}$

39 Des Moines Valley Whig, June 1, 1854;. The Davenport Gazette, June 8, 1854.

40 Herriott, "James Grimes Versus the Southrons," 404.

41 Des Moines Valley Whig; March 23, 1854; Sparks, "The Birth of the Republican Party in Iowa, 1848 to $1860, " 72$. 
Anti-Nebraska meetings at Davenport, Muscatine, Anamosa, Elkader, and Burlington, and in Washington, Henry, and Linn counties, adopted resolutions condemning the Nebraska act for repealing the Missouri Compromise and for conspiring to extend slavery into the free territories of the United States. The assembly in Washington county also passed a resolution vowing to withhold votes from any man running for public office "who is not decidedly in favor of a prohibitory liquor law." Other meetings endorsed James Grimes, attacked such renegade Whig journals as the Burlington Hawk-Eye, and applauded the Muscatine paper for opposing the Douglas measure. The anti-Nebraska gathering in Linn county adopted a plank endorsing the Democratic national platform of 1852 and insisted that persons in attendance were loyal Democrats who wanted no part of "Unjust or despotic measures." In Muscatine a segment of the Democratic party split from the parent body on the Nebraska issue and came out against a pro-Nebraska ticket in that county. The meeting at Elkader, claiming to be the first anti-Nebraska convention in the state, urged the repeal of the Fugitive Slave Law, and nominated an . anti-Nebraska ticket dominated chiefly by former Whigs. ${ }^{42}$

That the Nebraska controversy was the principal issue during the campaign of 1854 in Iowa cannot be conclusively and irrefutably demonstrated, but that the Iowa Democracy was divided on this issue is beyond question. Actually, the schism within the Democratic organization ran deeper than the Nebraska business. Other points of disagreement contributed to the disruption of the party's unity.

Two years earlier disputes over railroad projects had caused the defeat of the Democratic candidate in the Second Congressional: District. The question of state constitutional revision provoked considerable intramural strife. Internal improvements and homestead proposals also had produced serious friction within the ranks. ${ }^{43}$

42. Burlington Daily Telegraph, March 21, July 18, 19, 21, 25, 27, Aug. 19, 1854; Des Moines Valley Whig, March 30, 1854; History of Clayton County Iowa (Chicago, 1882), 419-420.

43 Morton M. Rosenberg, "The Democratic Party of Iowa 1850-1860." Unpublished Ph. D. Dissertation (State University of Iowa, 1957), 86-90. 
Moreover, the temperance issue was political dynamite to the party. The Rev. Henry Clay Dean, a fiery preacher of the Gospel, frontier-style, was a firm supporter of temperance. $\mathrm{He}$ addressed letters to the gubernatorial candidates requesting their views on temperance. Not wishing to reveal their sentiments too plainly, Grimes and Bates both replied that they would not veto a measure of the Legislature which provided for prohibition. The Rev. Mr. Dean then took to the stump for the Democrats and became a source of no little embarrassment to the party, especially in the anti-temperance areas. ${ }^{44}$

Meanwhile, Democratic papers picked away at Grimes for deciding to stump the state after he had stated that his first "Address" had precluded such activity. The Iowa Capital Reporter accused him of taking to the stump because he realized that his initial pamphlet had failed to deceive the public. ${ }^{45}$ The Iowa State Gazette charged that Grimes had always intended to canvass the state. ${ }^{46}$ The Mount Pleasant Observer, however, friendly to Grimes, explained that he returned to Iowa to answer the accusations of the Washington Union. ${ }^{47}$

Grimes opened his tour of Iowa at Mount Pleasant on the 29th of May, remained in the southwestern portion of the state for about a week, and then headed for the western counties. Writing to his wife from the Missouri Slope, he informed her that he met with strong opposition from pro-Nebraska men, especially in Pottawattamie county, and from anti-temperance partisans ${ }^{48}$ Toward the end of June, Grimes began to work his way eastward through the central counties. Despite his energetic stumping, Democrats were confident of victory. About three weeks before election day, Grimes himself acknowledged the strength of these sentiments as his own op-

44 Curtis Bates to Henry Clay. Dean, March 8, 1854 quoted in Burlington Daily Telegraph, March 27, 1854; James Grimes to Henry Clay Dean, March 2, 1854 quoted in William Salter, The Life of James W. Grimes (New York, 1876), 50.

45 May $31,1854$.

46. June $14,1854$.

47 Quoted in The Davenport Gazette, June 8, 1854, and in Des Moines Valley Whig, June 21, 1854.

48 James Grimes to Mrs. Crimes, June 4, 16, 18, 1854, quoted in Salter, James W. Grimes, 51-52; Des Moines Valley Whig, June 1, 12, 1854 . 
timism waned. On July 13 , he sent a call for aid to Salmon P. Chase and Elihu Washburne, asking for letters to assist him in his campaign. ${ }^{49}$

Grimes' efforts to draw the Germans away from the Democratic banner, however, apparently were meeting with some success despite their dislike of temperance legislation. The Germans, moreover, had already been stirred up in some counties because they believed they had been prevented from exercising a proper share in the selection of delegates to attend the state Democratic convention. Five days before the election a prominent Democrat in Davenport, James Grant, predicted that many Germans would leave the party. He expressed heightened alarm because Grimes was scheduled to return to Davenport again. ${ }^{50}$

The press of both parties, of course, continued to flail at each other. The Tribune of New York, widely circulated in Iowa, praised Grimes as "a man of abundant talent" and lauded his first "Address." Conversely, Democratic papers hailed Curtis Bates as "an amiable, honorable, and intelligent man." Bates was a worthy Democrat because he was loyal to the party, and above the squabbles of the past few years. Grimes, on the other hand, was a thorough abolitionist, and the Whigs were captives of the radical elements with whom Grimes had made his bargain. ${ }^{11}$

Though the Nebrsaka issue received widespread publicity, various local topics of controversy were even more significant to the voters. Whig journals continued to press for constitutional changes to permit banking, but Democratic papers, still frightened by the spectre of Eastern financiers and speculators, opposed such changes. The need for banking, averred one paper, was spurious and unfounded. These institutions were established merely to enrich bankers at the expense of the rest of society. The printing of paper money, which would

49 A. W. Carpenter to Laurel Summers, July 1.6, 1854; Sparks, "The Birth of the Republican Party in Iowa, 1848 to 1860," 103.

50 Burlington Daily Telegraph, Jan. 6, 8, 1854; James Grant to Laurel Summers, Aug. 2, 1854; The Davenport Gazette, Aug. 10, 1854.

51 New York Tribune quoted in Des Moines Valley Whig, May 11, 1854; The Davenport Gazette, July 13, 1854; The Iowa Weekly Republican, July 7, 1854; Iowa State Gazette, Jan. 18, 1854; Democratic Banner, April 14, 1854. 
accompany the legalization of banks, was "not only unnecessary but vicious" and was useful only to bankers. Most editors, however, were willing to permit the voters to decide whether they desired a revision of the constitution. ${ }^{52}$

Nor did the state press overlook the growing demand tor homestead legislation. Whig journals charged that the passage of the Nebraska bill had doomed homestead legislation. They asserted that Democrats would never enact homestead legislation because the party was controlled by slavery interests that had no desire to see free labor encouraged to migrate to the territories. But the Whigs could not with honesty accuse Iowa's Congressional delegation of laxity on this score, for Iowa Democrats had been working persistently for a homestead law. The state Democratic press also welcomed a homestead act; such legislation, it was claimed, would benefit the country by draining the surplus population from the cities. ${ }^{53}$

To counter Whig charges that they were anti-foreign, Democrates strove to identify Grimes and other Whigs with the Know-Nothing organization, a group whose reason for being was a strong antipathy to foreigners and Roman Catholics. Except during political campaigns, Democrats declared, Whigs and Know-Nothings worked hand in hand against the foreign-born population. In an election year, however, the former pretended to sympathize with the imigrants from other nations. And this was the Whig game during the current campaign: "Mr. Grimes and others, who heretofore have turned up their aristocratic noses at our fellow citizens of foreign birth, pretend to be wonderfully concerned about the rights and interests of those who happen to have been born on the banks of the Rhine or Shannon. It is astonishing how liberal Whig candidates become toward foreigners just about election time." 54

52 Dubuque Express and Herald quoted in The lowa Capital Reporter, Oct. 4, 1854; Eddyville Free Press, Dec. 22, 1854.

53 George M. Stevenson, The Political History of the Public Lands (Boston, 1917), 221; Burlington Daily Telegraph, July 27, 1854; Des Moines Valley Whig, March 9, 1854; Congressional Globe 1st Session 33rd Congress, 1667; Iowa State Gazette, Jan. 4, 1854.

54 lbid., June 14, 1854. 
The question of relocating the state capital also played a role of some importance in the campaign. Sentiment in favor of removing the capital to Des Moines, a place more suitably located than Iowa City, had been gathering momentum. Because Curtis Bates was a Des Moines resident, the friends of the Iowa City location viewed him with suspicion. Moreover, in Des Moines itself there was a ridiculous struggle between the east and west portions of the town over the actual site of the capitol building. Residents of the eastern side suspected that Bates, an inhabitant of the western portion, favored his own sector as a site. ${ }^{55}$

While the gubernatorial contest raged throughout the state, the Congressional races were disputed with equal vigor. In the First District Augustus Hall, campaigning on a strong proNebraska platform, had a distinct advantage over his lesserknown rival, Rufus L. B. Clarke, in this normally Democratic sector. ${ }^{56}$. In the Second District the Whigs sought to retain the seat which John P. Cook had wrested from the Democrats in 1852. Here Stephen Hempstead ran as a pro-Nebraska, antitemperance candidate against James Thorington who eschewed these sentiments. The Know-Nothing association of the latter had not yet come to light. Both candidates engaged in a series of debates which extended throughout the District. In Thorington the Whigs had a man who could unite temperance advocates, abolitionists, anti-Nebraska men, and nativists. $^{57}$

When the smoke of political battle had at last cleared and the votes cast on August 7 had been tabulated, the results indicated that the Whigs and the Democrats had fought one another to a stalemate. In the fight for the Legislature the Whigs took forty of the seventy seats in the House, but the Democrats captured the Senate sixteen to fifteen. On a joint ballot, however, the Whigs would control the General Assembly. Of the minor state offices the Democrats carried

55 Snyder, "Curtis Bates," 304.

56 The Iowa Weekly Republican, July 12, 1854.

57 The Davenport Gazette, July 27, 1854; Dubuque Miners' Express quoted in Des Moines Valley Whig, July 26,$1854 ; \mathrm{R}$. Christie to I-aurel Summers, July 18, 1854; Ceorge W. McCleary to Laurel Summers, July 20,1854 . 
everything save the position of auditor. ${ }^{58}$

The Whigs retained their control in the Second Congressional District where James Thorington trounced Stephen Hempstead by a vote of 11,424 to 9,772 . In the First District Augustus Hall shaded his Whig rival Rufus Clarke by less than 175 votes, 11,213 to 11,042 . James Grimes' tireless campaigning bore ample fruit, for he defeated Curtis Bates 23,325 votes to $21,202 .{ }^{59}$

Whigs, naturally, rejoiced at the outcome of the election. For the first time in the brief history of the state the Democrats had lost the gubernatorial office as well as one branch of the General Assembly. One Whig paper, carried away by its own exuberance, exclaimed that "the recent election of Iowa can only be properly expressed by styling it a revolution." 60 According to this journal the reason for the Whig victory was evident: the repeal of the Missouri Compromise brought the downfall of the Democracy. Grimes, himself, was only slightly more modest in his appraisals of the results. To Salmon P. Chase he wrote: "I fought the battle nearly alone. My colleagues on the congressional ticket were dead weights; I was too much of a Free Soiler; and I had the Burlington Hawk-Eye, a professedly Whig paper, and the silver-grey interest openly against me." 61

The defeat of Curtis Bates stunned the Democratic press. One journal blamed the failure of the ticket, and of Hempstead in particular, upon the temperance issue. ${ }^{62}$ In Washington the Union weighed the results and decided that:

... the causes are apparent and unquestionable. The Whigs took ground against that clause in the radical constitution of the State prohibiting all banking in the State, and made that an issue, while they rallied on the temperance question with all their force. Of course, the Nebraska bill was made the pretext of excitement, although the element had less to do with the canvass than is supposed. 63

58 Pelzer, "The History and Principles of the Democratic Party of Iowa." 211, Election Recordis 1848-1860.

59. Ibid.

60 Cincinnati Gazette quoted in Des Moines Valley Whig, Aug. 30, 1854.

61 James W. Grimes to Salmon P. Chase, Oct. 3, 1854 printed in Salter, James W. Grimes, 54.

62 lowa State Journal and Sunbeam, Sept. 1, 1854, quoted in Dan E. Clark, "The History of Liquor Legislation in Iowa, 1846-1861," Iowa Journal of History and Politics, XV, 1917, 71.

63 Quoted in the Iowa Capital Reporter, Sept. 6, 1854. 
Another Democratic paper pointed out that Whig control of the Iowa Legislature would terminate the Senatorial career of A. C. Dodge, whose term was to expire in 1855. That a Whig would replace him was now a foregone conclusion. ${ }^{64}$

The factors underlying Grimes' victory were, of course, complex. No single issue alone can explain his triumph. Employing the Nebraska question with consummate skill, Grimes presented a moral panoply under which several dissimilar groups could unite politically. Disdaining the support of oldline national Whigs, Grimes relied upon the more radical segments of the party and combined them with anti-Nebraska men, Free Soilers, Know-Nothings, Abolitionists, temperance advocates, and disgruntled Democrats. The latter had grown dissatisfied with the Democratic party because of quarrels over internal improvements, constitutional revision, railroad projects, and homesteads. The matter of relocating the state capitol also operated to the disadvantage of the party.

The Democrats, in part, contributed to their own downfall. Believing that the state would remain safely under their control, they did not wage as active and as thorough a campaign as did Grimes and his supporters. Only excessive over-confidence can explain the failure of party leaders in Washington to return to Iowa to work for the party ticket. To be sure, Congress was in session during a good part of the time, but even in the crucial stages of the canvass no one returned to Iowa to assist the state ticket. ${ }^{65}$

But more than anything else, the victory of James Grimes was a personal triumph, a fitting reward for his tireless labor and his energetic stumping as well as political acumen. A more intensive effort on the part of Curtis Bates might well have given him the election, for even with the moral and emotional heat which Grimes had generated, the outcome of the election was exceptionally close and far from decisive.

Had the Iowa Whigs conducted their campaign solely on the basis of their opposition to the Kansas-Nebraska Act, they

64 Milwaukee News quoted in Ibid., Sept. 6, 1854.

65 Cf. Milton, Eve of Conflict, 173; Herriott, James Grimes Versus the Southrons," 428; Sparks, "The Decline of the Democratic Party in Iowa," 19; Sparks, "The Birth of the Republican Party in Iowa, 1854$1856, " 17$. 
would undoubtedly have been defeated by their opponents. Local issues of vital concern to the citizens of the state motivated the voters more effectively and decisively than did the Nebraska agitation. What the Nebraska law did do was to provide the adhesive element which enabled the Whigs to fuse the various special interest groups into a solid unit of opposition to the Iowa Democracy. This was the essential significance of the Kansas-Nebraska issue in Iowa.

\section{Hill's Mill}

In 1868 William L. Hill and his brother Thomas moved to Linn County and purchased a mill known then as McQueen's Mill. This mill was built in 1853-4 by Mr. John McQueen and passed through several hands before Mr. Hill purchased the mill and 25 acres of surrounding property. The business prospered and the Hill's Mill on Buffalo Creek became known as the "best mill in this part of the state." In addition to the mill, William owned and operated a farm of 120 acres in Boulder Township.

William was born in Bradford, Yorkshire England, the son of one of the first photographers in England, in April, 1836. He received most of his formal education in Bradford, attending high school and several colleges there. At 15 years of age he was commissioned to learn the milling trade at Skipton, England, and worked and studied there for five years. In 1857 he crossed the Atlantic and settled for a time in York, Canada, then to Embra, Canada, finally traveling to Buffalo, N.Y. to further his education at Bryant and Stratton College.

After working several places, including jobs in New York and Indiana he settled in Iowa after buying the McQueen's Mill. In 1875 he traveled back to Canada and married Miss Catherine Wilkinson, whom he knew in England, and brought his new bride to Iowa. They had three children-Alice, Wil- 
Copyright of Annals of Iowa is the property of State of Iowa, by \& through the State Historical Society of Iowa and its content may not be copied or emailed to multiple sites or posted to a listserv without the copyright holder's express written permission. However, users may print, download, or email articles for individual use. 